\title{
Research on the Curriculum System Design of Engineering Cost in Mainland China Based on Professional Competence Standard Hua Zhao ${ }^{a^{*}}$, Xing $\mathrm{Li}^{a}$, Hui-jie Jiang ${ }^{b}$ and Xiao-ting $\mathrm{Yi}^{a}$ \\ ${ }^{\text {a }}$ School of Accounting, Wuhan Textile University, Hubei, China \\ ${ }^{\mathrm{b}}$ School of Construction \& Environment Engineering, Shenzhen Polytechnic, Guangdong, China \\ *Corresponding author: Hua Zhao, Ph.D., zhao_hua_08@163.com
}

\begin{abstract}
The constant adjustment and optimization of the curriculum system is an important issue about the major construction of engineering cost, which directly impacts on the success or failure of talent training in Chinese universities or colleges. Based on literature review and benchmarking, the paper summarizes the meaningful international experience and constructs a suggested competence standard for engineering cost professionals, and designs a professional curriculum system for undergraduates majoring in engineering cost. The research results of the paper have some guiding significance to the major construction and curriculum reform of engineering cost in related Chinese universities or colleges.
\end{abstract}

Key words: curriculum system design; engineering cost; professional competence standard; course reform; engineering cost consulting industry; mainland china

\section{Introduction}

In the past two decades, the construction scale of the engineering cost (EC) major has expanded rapidly, and the employment situation of graduates has been very good. But in recent years, the employment situation has begun to show certain structural contradiction that is graduates cannot easy to find a suitable job and employing units cannot easy to recruit the right staff. The main reason is maybe that there is mismatching between the competence structure of graduates majoring in EC and the employing units' demanding, ${ }^{1,2}$ which puts forward a great challenge to the construction of EC major in China. In foreign construction practice of EC major, a variety of specialized industry associations played an important intermediary role in the professionals training process by means of developing the core competence standards and providing competence certification for related professionals. ${ }^{3,4}$ The core competence standards of professionals developed by related industry associations can reflect the demanding for the ability level and its structure in the talent market, ${ }^{4}$ which has important guiding significance to the professionals training in the related universities.

Unfortunately, in mainland China, the industry associations usually do not have the abovementioned intermediary functions. Therefore, it is an important task to analyze the changing ability demand of the talent market and to design a reasonable curriculum system for the construction of EC major in related universities or colleges, which has become one of the key abilities to the successful major construction strategies. It is in this sense, after analyzing and summarizing the core competence standards of EC major in typical countries and regions by benchmarking, the paper constructs the core competence system of EC major and related 
curriculum system for related universities or colleges in mainland China, which have some guiding significance to course reform and training program optimization of the EC major.

\section{Literature review}

\subsection{The logic of constructing competence standard system on EC}

Ability refers to a serial of necessary skills of people when they engaged in one or several similar occupations. It is a kind of comprehensive ability which it is taking practice as the carrier and its purpose is solving the problems. ${ }^{5}$ The related research on competence standard construction mainly includes the following two aspects. Firstly, some researchers explored the formation of competence standards and its mechanism from the perspective of professional certification system, the research results revealed that a serial of competencies directly reflecting the requirement of the market, the employers and the industry standards for professional practitioners in the field of business practice. ${ }^{6}$ This study reflects the output logic, belonging to ex post control, ${ }^{7}$ and guide the construction of the standard system of professional certification. Secondly, other researchers studied the elements of competence standard from the perspective of professional competence evaluation, ${ }^{8}$ and the researches reflecting a certain constructivist logic, but its operability is very strong. The above two kinds of logic have been integrated, and there have been a series of mature competence standard system on quantity surveying (QS, as known as EC in the Chinese mainland). ${ }^{9}$

Table 1 - The characters of QS professional certification system in typical countries and regions

\begin{tabular}{|c|c|c|c|c|}
\hline $\begin{array}{c}\text { Country or region } \\
\text { (industry association) }\end{array}$ & $\begin{array}{l}\text { Certification } \\
\text { standards }\end{array}$ & Core contents & $\begin{array}{c}\text { Competence } \\
\text { evaluation criteria }\end{array}$ & $\begin{array}{c}\text { Evaluation } \\
\text { method }\end{array}$ \\
\hline UK. (RICS) & \multirow{4}{*}{$\begin{array}{l}\text { Competence } \\
\text { standard } \\
\text { system }\end{array}$} & $\begin{array}{l}\text { Responsiveness of curricula to } \\
\text { competency standards }\end{array}$ & $\begin{array}{l}\text { Compulsory and } \\
\text { core competencies }\end{array}$ & Interview \\
\hline Australia (AIQS) & & $\begin{array}{l}\text { Course } \quad \text { contents, } \quad \text { student } \\
\text { enrollment } \quad \text { standards, teaching } \\
\text { staff and teaching conditions }\end{array}$ & $\begin{array}{l}\text { Basic and core } \\
\text { competencies }\end{array}$ & Interview \\
\hline Singapore (SISV) & & $\begin{array}{l}\text { Basic profile of professional } \\
\text { courses, admission conditions, } \\
\text { educational processes, etc }\end{array}$ & $\begin{array}{l}\text { Basic and core } \\
\text { competencies }\end{array}$ & Interview \\
\hline Hong Kong (HKIS) & & As same as United Kingdom’s & core competencies & Interview \\
\hline
\end{tabular}

Notes: RICS- Royal Institution of Chartered Surveyor, AIQS- Australian Institute of Quantity Surveyors, SISV- Singapore Institute of Surveyors and Valuers, HKIS- the Hong Kong institute of Surveyors. Source: edited from Ling YAN et al. ${ }^{9}$

\subsection{The professional certification system and competence standard system on EC}

Britain's QS system has a wide range of demonstration significance, and its professional certification system is a link between higher education and the registration practice system for QS professionals, emphasizing the higher education qualifications of QS professionals must be certified by a qualified industry association..$^{10,11}$ By comparing the professional certification system of the higher education system of QS (or EC) in the typical several countries and regions, some meaningful conclusions are shown in Table 1.

As shown in Table. 1, the key to the QS certification system in typical countries and regions is to examine whether the curriculum system in related universities or colleges are responsive to the core competency standards existing in the Assessment of Professional Competence 
(APC), which maybe ensure that the graduates have access to the necessary professional work skills. ${ }^{9}$

In summary, the research on the competence standard of EC professional is not yet mature, but many scholars have carried out a series of studies, such as Lin YAN et al ${ }^{9}$., Jin HONG et al. ${ }^{11}$, Su-qin SUN et al. ${ }^{12}$, etc. Based on the existing research results and the national benchmarking approach, it will help to better design the core competency standards of EC professionals and promote the optimization of professional curriculum reform.

\section{The construction of competence standard for EC professionals in mainland China}

\subsection{An analysis of competence standard for EC professionals based on benchmarking}

As the birthplace of the quantity surveyor, the United Kingdom has gradually prepared the internationally recognized professional system for the surveyors after more than 100 years developments. Since RICS is specifically responsible for the editing and revising of the professional system, it is also known as the RICS standard, which has had a profound impact on the construction of professional system for QS in commonwealth countries and the AsiaPacific regions. As shown in RICS standard, the professional competence system of QS consists of three levels: compulsory competence, core competence and expert competence. ${ }^{10}$ Analysis of the professional competence standards for international QS is shown in Table 2.

Table 2 - The analysis of QS professional competence standards in typical countries and regions

\begin{tabular}{|c|c|c|}
\hline Level & $\begin{array}{l}\text { United Kingdom /Hong Kong } \\
\text { (RICS/HKIS) }\end{array}$ & $\begin{array}{c}\text { Asia-Pacific/Australia \& Singapore } \\
\text { (AIQS/SISV) }\end{array}$ \\
\hline 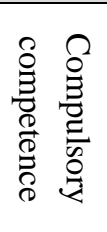 & $\begin{array}{l}\text { 1)Ethics and professional norms, 2)Customer } \\
\text { demands, 3)Communication and negotiation, } \\
\text { 4)Leadership \& teamwork, 5Rresource } \\
\text { management,6)Accounting principles, } \\
\text { 7) Data management. }\end{array}$ & $\begin{array}{l}\text { 1)Measurement Technology, 2)Communication } \\
\text { Skills, 3)Ability to work independently, } \\
\text { 4)Professional Practice, 5) Information } \\
\text { Technology, 6)Construction Technology, } \\
\text { 7)Construction Law and Regulation. }\end{array}$ \\
\hline 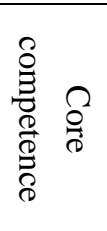 & $\begin{array}{l}\text { 1)Construction business management or design } \\
\text { economics, 2)Cost estimation, 3)Construction } \\
\text { technology and environmental services, } \\
\text { 4)Procurement and bidding, 5)Financial control. }\end{array}$ & $\begin{array}{l}\text { 1)Strategic Planning,2)Budgeting \& cost } \\
\text { estimation, 3)Procurement and bidding, } \\
\text { 4) Bill of quantities, 5) Accounting management, } \\
\text { 6)Construction change management, JFeasibility } \\
\text { study. }\end{array}$ \\
\hline 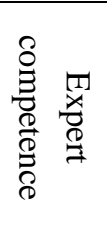 & $\begin{array}{l}\text { 1)Cost optimization, 2)Contract management, } \\
\text { 3)Programming and planning,4)Pproject } \\
\text { evaluation, 5)Risk management, 6)Conflict } \\
\text { avoidance, management and dispute resolution } \\
\text { procedures, 7)Sustainable development. }\end{array}$ & $\begin{array}{l}\text { 1)Pre / post audit, 2)Quality assurance, } \\
\text { 3)Cost information database,4)Claims and } \\
\text { dispute resolution, 5)Financial audit, 6)Life cycle } \\
\text { management, 7)Value management. }\end{array}$ \\
\hline
\end{tabular}

As shown in Table 2, some meaningful conclusions are summarized as follows:

A. The typical countries and regions are concerned about the basic ability of training including measurement and computer technology and other basic business, but the United Kingdom /Hong Kong paid more attention to the individual ethics and customer satisfaction.

B. At the level of core competence, the standards of the countries and regions above are the same. Many professional qualities of qualified QS are summarized into the depth requirements of the surveyor's skills and knowledge.

C. For the expert competence, the countries and regions above emphasis on the essential skills for the complete service in life cycle of the project, those are the future scalability. 


\subsection{The construction of competence standard for Chinese EC professionals}

\subsubsection{An Analysis of the Actual Situation of Chinese Engineering Consulting Industry}

The Chinese consulting industry is still in the stage of rapid development and its practical situations differ from which in the developed countries or regions. At present, the actual situations and development trends of Chinese engineering consulting industry can be summarized as follows:

A. Diversification of professional engineering and its implementation regulation is not uniform. In China, construction projects are subdivided into housing construction, civil engineering, municipal gardens, bridges and tunnels, ports and other different professional projects. There are existing different implementation methods and different professional techniques standards in different professional projects. Therefore, for the EC consultants, they have a wide range of practice areas that require diverse and segmented expertise.

B. Engineering consulting firms require graduates to adapt to job requirements as quickly as possible, with a particular focus on practical skills. At present, the homogeneity of Chinese engineering consulting enterprises is common, the price war has become an important business strategy, which results in the utilitarian idea of hiring employees is obvious, the enterprise specially emphasis on the practical ability of graduates.

C. The calculation of engineering quantities and the confirmation of project prices are still the main business areas of graduate employment. In the past, the EC management business in mainland China was mainly confined to the cost of planning and control of construction projects. Although the functions of the EC management are no longer single with the deepening of market economic system reform, the scope of its business is still relatively narrow compared with foreign counterparts. For many fresh graduates, the calculation of engineering quantities, cost estimating and cost control are still the main business in long time.

$D$. The informatization of the engineering consulting services is very rapid. In recent years, the EC consulting industry continues to improve the level of informatization in mainland China, a large number of professional software has become the industry's conventional tools, especially BIM (Building Information Modeling), VR (Virtual Reality) and other new technologies continue to apply in the traditional EC consulting industry, which will bring unprecedented challenge for graduates majoring in EC.

\subsubsection{A suggested Competence Standard for Chinese EC Professionals}

The employment strategy of Chinese EC consulting market shows a strong utilitarian ideology and emphasizes that new employee can adapt to job requirements as quickly as possible. The talent market of Chinese EC professionals places more emphasis on the basic competence and core competence level. Although this logic above may not be correct, the current Chinese universities must consider this market appeal when they developed the training mode of EC professionals. Therefore, the direct use of the QS competence system in typical countries or regions cannot adapt to the demanding of EC professionals training for the relevant universities in China. The construction of the core competence standard for Chinese EC professionals must take into account Chinese reality when we learn from the useful experiences of typical countries or regions. According to the aforementioned logic, a suggested competence standard of EC professionals is shown in Table 3. 


\section{The curriculum system design of engineering cost in Mainland China}

The professional curriculum system is one of the important systems designing of university talent cultivation, which is a collection of professionals' competencies reflecting the minimum competence standard of the training unit for the graduates. A good curriculum design should cover the various competencies in the competence standard and be helpful to teaching organization and management. By analyzing the components of the competence standard, the curriculum design of EC majors in China is shown in column 3 of Table 3.

Table 3 - A suggested competence standard and courses system of EC professionals

\begin{tabular}{|c|c|c|}
\hline Level & Competencies & Courses list \\
\hline \multirow{6}{*}{ 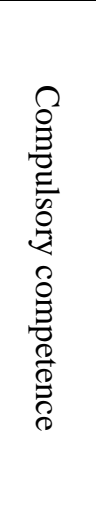 } & Professional ethics & \multirow{2}{*}{$\begin{array}{l}\text { 1)Foundation of humanities and social sciences, 2)Introduction to } \\
\text { EC, 3)Career planning, 4) Economic law, 5) Construction laws and } \\
\text { regulations, 6) Principles of contract law }\end{array}$} \\
\hline & $\begin{array}{l}\text { Construction Law and } \\
\text { Regulation }\end{array}$ & \\
\hline & Architecture Technology & $\begin{array}{l}\text { 7)Engineering drawing, 8) Engineering survey, 9) Engineering } \\
\text { materials, 10) Engineering mechanics, 11) Engineering construction } \\
\text { technology, 12) Introduction to civil engineering }\end{array}$ \\
\hline & $\begin{array}{l}\text { Fundamentals of Economics } \\
\text { and Management }\end{array}$ & \multirow{2}{*}{$\begin{array}{l}\text { 13) Principles of management, 14) Principles of economics, 15) } \\
\text { Foundation of accounting, 16) Engineering economics }\end{array}$} \\
\hline & Communication Skills & \\
\hline & Information Technology & $\begin{array}{l}\text { 17) Information science and technology, 18) Computer technology } \\
\text { and application }\end{array}$ \\
\hline \multirow{8}{*}{ 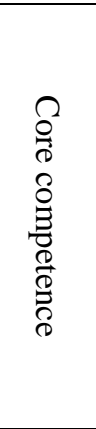 } & Measurement Technology & \multirow{4}{*}{$\begin{array}{l}\text { 19) Principles of engineering quota, 20) Construction organization } \\
\text { design and management, 21) Engineering Measurement and } \\
\text { valuation, 22) Engineering cost management }\end{array}$} \\
\hline & Cost estimating \& control & \\
\hline & Cost optimazation & \\
\hline & Bill of quantities & \\
\hline & Project procurement & \multirow{2}{*}{$\begin{array}{l}\text { 23)Project management, 24)Engineering management, 25) Bidding } \\
\text { and contract management, 26) Construction project contracting } \\
\text { management, 27) Contract management of international project }\end{array}$} \\
\hline & Contract management & \\
\hline & Informatization of EC & 28)Software of EC management and engineering management \\
\hline & Project financing & 29) Engineering finance, 30) Project financing \\
\hline \multirow{7}{*}{ 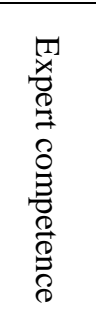 } & Customer relationship & 31)Customer management \\
\hline & Project evaluation & 32)Project feasibility study and evaluation \\
\hline & Auditing of EC & 33)Project auditing \\
\hline & Dispute resolution & 34)Project conflict management \\
\hline & Engineering change/claim & 35)Engineering change and claim management \\
\hline & Value Management & 36)Value management, 37)Project value management \\
\hline & Life cycle cost manahement & 38)Theory of life cycle cost management \\
\hline
\end{tabular}

\section{Conclusions}

In today's China, the EC talents training of university must quickly respond to the demanding of industry development. One of the successful experiences of China's reform and opening up is to combine the international universal truth with China's concrete practice. According to this logic, the paper analyzes the construction logic and the characteristics of QS professional certification system by literature review, and summarizes QS professional competence standard into 3 levels such as compulsory competence, core competence and expert competence. And then, a suggested standard of professional competence for EC in mainland China is constructed by benchmarking. At last, the paper put forwards a professional curriculum system for undergraduates majoring in EC through analyzing the matching 
relationship between the aforementioned competence system and professional courses. The research results have some guiding significance to the major construction and curriculum reform of EC in related Chinese universities or colleges.

\section{References}

1. G.F.Zhu, Chinese engineering education: present and future, J. Tsinghua Journal of Education, 1 (2015) 13-20.

2. Z.Y. Zhang, S.L.Wang, The construction of cooperation mechanism between application universities and industry organisations, J. Chinese University Science \& Technology, z1 (2012) 58-59.

3. J.J.Bi, Redesigning program specifications focusing on quality education, J. Comparative Education Review, 1 (2006) 22-27.

4. M.G.Li, On the global strategies of China's higher engineering education, J. Research in Higher Education of Engineering, 6 (2008) 1-12.

5. D.Y.Yang, Three-dimensional connotation of students practice ability, J. Modern University Education, 4 (2012) 6-11.

6. H.B.Kong, Y.Q.Qiu, On engineering qualification framework and competence standards, J. Research in Higher Education of Engineering, 6 (2010) 9-19.

7. J. C.Lucena, Flexible engineers: history, challnges, and opportunities for engineering education, J. Bulletin of Science, Technology \& Society, 6 (2003) 419-435.

8. L.Yan et al., On the assessment mode of double certificate accredidation in cost engineering in application-oriented undergraduate, J. Research in Higher Education of Engineering, 5 (2014) 72-78.

9. L.Yan, YiL.Yin, Study on professional certification system: based on the sample analysis of the quantity surveying major in Britain and Asian-Pacific regions, first ed., Tsinghua University Press, Beijing, 2013.

10. R.P.Wang, et al. Linkage between US system of accreditation in higher engineering education and professional engieer certification system, J. Tsinghua Journal of Education, 1 (2015) 34-40.

11. J.Hong, X.Shu, A study on the self-running ability of industry association of China, J. Journal of Beijing Institute of Technology(Social Sciences Edition), 6 (2012) 50-54.

12. S.Q.Sun, Y.A.Gu, The structure and basis of applied talents in training system, J. Modern Education Management, 9 (2012) 72-75. 